\title{
MOTIVATION IN BUSINESS ORGANIZATIONS
}

\author{
Ganesh Prasad Niraula \\ Department of management, TU, Thakur Ram Multiple Campus, Birganj, Nepal \\ email: gniraula83@gmail.com
}

Abstract
Motivation is the most important tool for modern organizations. Motivation
actually crates drive that leads to the achievement of the individual as well
as the organization's objectives. Now a days many management experts have
focused their studies in this field. Moreover not only business organizations,
other types of organizations need motivation to obtain their desired goals. It is
vital element in the field of education too, as we know very well that a teacher
persuade and create drive the students to learn new things and lesson. The
present study focuses on concept of motivation, importance of motivation and
techniques of motivation at work places.

\section{Keywords}

Drive; perception; intercede; sludge; subordinate; gimmick

\section{Introduction}

The term motivation is derived from the word 'motive'. As a noun the word motive means an objective and as a verb it means moving into action. Therefore, motivation is a force which leads people to act to fulfill objectives. It cannot be directly observed but can only be inferred from behavior. It is also partly influenced by a worker's perception, learning, ability and personality traits. Management gets the work done by working with and through people to achieve organizational goals. Motivation is the key to management to achieve effective work performance from workers.(K.C 2004)

Agrawal (2005) cites in his book principles of management as motivation is a psychological and human aspect. It is the process of creating willingness among the employees to do work in best possible way. It is the act of inspiring employees to devote maximum effort to achieve organizational objectives. People do something to fulfill their basic and social needs. In other words, workers fulfill their duties efficiently to fulfill their needs, desires and wishes. Motivation is an instrument through which the management understands why and how workers interact and work in accordance with organizational requirements. It energizes the behavior of subordinates and directs them towards the attainment of common goals.

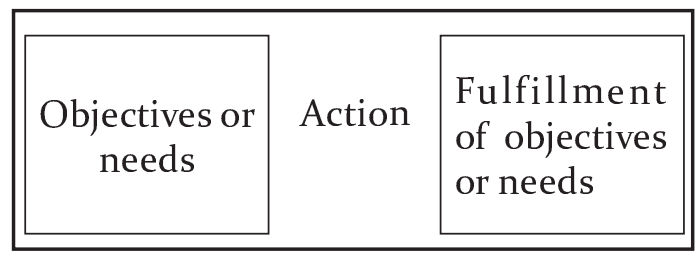


Decenzo and Robbins (2011) cited as" Motivation is willingness to exert high level of effort to reach organizational goals, conditioned by the effort's ability to satisfy some individual need."

Similarly dale s beach (1970) has cited in his book as" Motivation can be defined as a willingness to work to expand energy to achieve a goal or reward."

Therefore, motivation is the art of inspiring and encouraging subordinates to do work in an effective way so both organizational and individual goal can be achieved. In motivation, a manager must have the knowledge of why and how people act in accordance with organizational requirements. He must have the knowledge to do a particular work with clear vision. It is the responsibility of the manager to develop such an environment that workers can perform their work in best possible way.

\section{Importance of motivation}

Motivation is one of the important parts of managerial functions. The manager becomes failure if he fails to motivate his subordinates. There is a close relationship between motivation and performance. The following are the some importance of motivation (Paudel and Pradhan 2012)

1. Lead to profitable operation: Motivation is an important tool that leads the organization in profitable operations. Motivated workers perform their duties with full responsibility. The development of self responsibility among the workers contributes for the best utilization of available resources like materials, money, machines and others.

2. High level of productivity: Motivation contributes to develop working efficiency of employees. When employees are actually motivated they improve their working efficiency. The development of working efficiency among workers leads to maximize production and productivity. Management can expand its business activities in large areas for organizational profitability and growth.

3. Best remedy for resistance to change: The change in the management system and organizational structure is structure is essential to adjust an organization and its business activities according to changing environment. In some situation workers, especially, their unions may create resistance to change. They think about their job security and stability. The motivated workers have knowledge about the outcome of changes. They even better appreciate the management view points to the introduction of changes in the organization.

4. Effective use of human resources: Manpower is the main active factor of production and is responsible for the best utilization of organizational resources. Motivation is the main instrument which creates the willingness among workers to do their work in the best possible way. In other words, motivated employees make the best utilization of their skills, knowledge capabilities etc. in the existing environment.

5. Satisfaction of employees: The satisfaction of the employees is essential for organizational effectiveness. Motivation helps satisfy employees and develop morality among them. Employees with high morale become dedicated to the organization. They also perform their jobs in the best manner. Generally, employees are motivated through facilities both financial and nonfinancial. Financial facilities are essential to fulfill basic and other psychological needs. In a similar manner, promotion on the basis of efficiency is essential to fulfill social needs.

6. Minimizes disputes and strike: Motivation 
is an important tool, which helps to maintain coordination and develop a feeling of harmony among workers and management. It minimizes misunderstanding and disputes between the management and workers. The development of transparency about the internal matters stimulates the workers to perform their work efficiently. When workers get knowledge about their responsibility and return, they perform their work efficiently.

7. Basis of coordination: Motivation is the basis of coordination among all members of the organization. Motivates employees develop a better understanding among themselves. They appreciate their mutual problems and resolve differences through mutual consent. The main reason for the differences in approach among the workers is the lack of coordination. However, Motivation helps to maintain coordination among the workers. The maintenance of coordination helps to develop the attitude of team spirit and group effort for common goals.

8. Stability of workforce: It is known that a motivated and stable workforce is the potential of the organization. Motivation directly or indirectly facilitates the stability of the workforce. Generally, frustrated and dissatisfied employees may think of leaving the organization for better opportunity. Motivated employees do not want to leave the organization and want to work for the organization with the best possible way. Therefore, the management needs to provide facilities to workers on the basis of their efficiency and experience.

9. Minimizes supervision cost: Motivated employees perform their work themselves. In other words, the concept of self responsibility is developed among them and they perform work smoothly. For such employees, only guidance and timely suggestion is sufficient. Therefore, regular and close supervision is not required to such employees. Motivation indirectly contributes to minimizing supervision cost.

10. Achievement of organizational goals: Every organization is established to achieve definite objectives. Similarly, the main responsibility of the management is to focus on organizational objectives. Motivated workers put their effort toward the attainment of organizational objectives. The best utilization of human effort contributes for the proper utilization of other resources. This is helpful to minimize cost of output or service and maximize profitability.

\section{Techniques of employee motivation at workplace}

Motivating employees at work place has become a challenging job for managers and entrepreneurs. If the managers are leading the way in the changing work place they should provide suitable working environment for the employees and workers in the enterprise. From the beginning the employers and mangers have been using the same horrible and threatening motivation techniques for decades to trying to make their workforce more productive, but the world has changed and time has come to modernize the work place. Ressler (2013) has prescribed the following techniques of amazing employee motivation techniques at work place

1. Results-only work environment: the organization should focus on result rather than effort. Forget flexibility, go beyond telework, and just bypass all these gimmicks and programs that put the focus on time and presence. It focuses on results and is proven to increase productivity and employees retention, and boost customer satisfaction. You can read more about how it has been adopted across multiple industries and 
hear testimonials and stories from our satisfied clients.

2. Outcome-based goals and frequent reviews: just as bad goals and infrequent reviews are bad motivators, meaningful goals and frequent conversations about performance are extremely motivating. Outcome-based goal setting gets everyone aligned-first. This way, creating measurable results is effective and achievable. This framework is outcome-based thinking and generates an environment where performance is managed on a continuous basis. That means all the time, not just at the yearly performance review meeting.

3. Don't force. Reinforce: Another way of looking at aligning your incentives is the contrast between forcing and reinforcing. Are you manipulating and forcing your employees to be on their best behavior, or are you focusing on positives and reinforcing values?

\begin{tabular}{|c|c|}
\hline Force & Reinforce \\
\hline $\begin{array}{l}\text { This is the } \\
\text { behavior that's } \\
\text { Expected and } \\
\text { rewarded. }\end{array}$ & $\begin{array}{l}\text { These are the } \\
\text { results that are } \\
\text { Valued and } \\
\text { rewarded. }\end{array}$ \\
\hline $\begin{array}{l}\text { Do these things } \\
\text { whether you } \\
\text { like them or } \\
\text { not (they're a } \\
\text { necessary Part of } \\
\text { the job). }\end{array}$ & $\begin{array}{l}\text { As you can see } \\
\text { the outcomes } \\
\text { we're striving for, } \\
\text { determine the } \\
\text { best ways to get } \\
\text { them done. Here } \\
\text { are our standards, } \\
\text { patterns, } \\
\text { expectations. }\end{array}$ \\
\hline $\begin{array}{l}\text { Our bonuses are } \\
\text { reflective of our } \\
\text { "market pay" } \\
\text { analysis for your } \\
\text { job classification. }\end{array}$ & $\begin{array}{l}\text { Our bonuses } \\
\text { reflect the way we } \\
\text { share value that } \\
\text { you help create. }\end{array}$ \\
\hline
\end{tabular}

This approach to incentives is one of reinforcement, validation, alignment and unity. It says to employees that ownership sees them as key partners in building a unified financial vision for growing the business.

4. Financial Incentives: most of the people talked about the wrong way to use financial incentives and compensation as motivators. However, financial incentives can be a good way to motivate employees, as long as you use the, as part of a bigger plan and align these incentives with the workplace culture as a whole. We shared Vision Link_Advisory Group's_unhealthy incentives list with you last time. Conversely, a healthy view of incentives would have a company view their purpose as follows:

- Demonstrate a financial partnership with employees

- Communicate the outcomes and results most valued by the organization

- Create a flexible means of rewarding high performers as well as special circumstances and achievements

5. The bottom line is trust: Mistakes are opportunities to fix problems and move on, not overreact with new politics, rules and regulations. Employees are trusted as the experts that they are and expected to deliver results, or they don't have a job. If the employees gathering around the water cooler, gossiping about who took vacation or who is allowed to work from home. When there's no trust from leadership or among teams, then individuals don't trust each other either.

6. 'Focus on strengths: Your employees aren't you. They will do things differently than the way you do them, so help them play to their strengths! Your unique contribution makes the team great. So, bring it. Discover your genius. Be 
accountable for contributing your very best. Embrace the diversity of your team.

7. Coach and encourage: If micromanagers are like babysitters, then the bosses we all hope to have are like great coaches. What kind of boss are you, a micro-manager or a coach? Your management style is a huge factor in motivating your team. It's not just about the right incentives or the right programs or benefits packages. Do you bring out the best in your team? Take our simple quiz to see what kind of boss you are.

8. Motivated by freedom and responsibility: When managers try to mediate and direct too much, they limit our ability to exceed expectations. Some of the best places I've worked have been where my boss comes to me and says: 'Here's the big picture, this is what we need to accomplish, how you want to get it done?' that makes me feel great. When others are looking at me deliver great results, what's better motivator than that? I'm not motivated by a list of rules and parameters and politics, to be restricted that way."

9. Let employees figure out HOW they work best; don't give orders: Part of being a manager is paying attention to what matters. Managers must focus on the WHAT of work, and leave the HOW to the adults that have been hired. This is WHAT needs to be achieved (end result). Now go do it.

10. Treat your employees like adults: What is the role your employees play? What are the expectations you set for them? According to social expectations theory, we know that the people tend to adopt social norms and roles and to confirm their behavior to meet expectations. Step back and look at your employees' perception of their roles in your organization. Are they treated like adults or children?
Here's an example of social expectations in the workplace: Jim comes into work early because he knows you keep track of his time, pretends to be busy when you're watching, sneaks down the hall to gossip with co-workers, calls in sick (with extra coughing so you know he's not faking it!), and asks permission to leave early to see his kid at a her holiday program at school.

Shyam, a grown man, feels the need to act like a grade scholar - asking permission, sneaking around, looking busy, faking sick to get a day off. When you treat your employees like children, they will act like children.

11. Motivation is not a "program"; ultimately, if intrinsic motivation is absent then all else is a temporary fix at best. Motivation is not a program; it is a personal approach to dealing with individuals. Each person is likely motivated differently and in varying degrees. The key to motivation is knowing your people. You don't have to give away the farm to satisfy people's motivation. You only have to know them on a personal level and what drives them.

\section{Conclusion}

As we know motivation plays very important role in modern organizations. Most of the organizations are seeking experts' advice to motivateemployees in their business enterprises. Managers manage the organizations by using their best of knowledge and competencies; still they are deprived of using the appropriate techniques and tools of motivation due to misunderstanding the human behavioral aspect. In our country the managers of business organization follow the red-tapism and bureaucratic model of motivation technique which is very harmful for the enterprises in the long run. If any enterprise wants to enhance the effectiveness and productivity of the enterprise on the whole then they should understand the human behaviour and suggested to use suitable tools of motivation. 


\section{References}

Agrawal, G. R. (2005). Principles of management in Nepal, Kathamndu: M.K. Publishers and Distributors.

Beach Dale S, (1970). The management of people at work. Journal of Applied Behavioral Science.

Cali, R. (2013) Approved employee motivation ideas. New york: Harper and Row.

K.C., Fatta B. (2004). Principles of management. Kathmandu: Sukunda Pustak Bhawan.
Koontz, Harold \& Weihrich, Heinz (2002). A Global Prospective (5 $5^{\text {th }}$ ed.). New Delhi: Tata McGraw Publishing Co. Ltd.

Poudyal, S. R., Pradhan, G. M. (2012), Basic Management. Kathmandu: Asmita Books Publishers and Distributors (P) Ltd.

Robbins, S.P. and David A. Decenzo (2001).Fundamentals of management. Delhi: Pearson Education. 